\title{
COEXISTENCE OF TERRITORIALITY AND HAREM DEFENSE IN A RUTTING FALLOW DEER POPULATION
}

\author{
Fernando Alvarez, Francisco Braza, and \\ Caistina San Jose \\ Estación Biológica Doñana, Consejo Superior Investigaciones Cientif́cas, \\ Apartado 1056, Sevilla, Spain
}

Male fallow deer (Cerous dama) on the Swedish island of Öland (Espmark and Brunner, 1974) and in South Weald, England (Chapman and Chapman, 1975) apparently defend territories with a eentral area (rutting stand) heavily trampled and marked with the produets of seent glands and urine. Courtship and eopulation with visiting females occur there. Lek-breeding has been reported for fallow deer in SchleswingHolstem, north Germany (Heidemann, 1973), Jaegersborg, Denmark (Schaal, 1986; Schaal and Bradbury, 1987), Gyulaj, Hungary (Pemberton and Balmford, 1987), San Rossore, eentral Italy (Apollonio et al., 1989, 1990), and Petworth, England (Clutton-Brock et al., 1988; Pemberton and Balmford, 1987); some males at the last two localities also defended individual-resouree territories.

At Doñana National Park, in southern Spain, males follow and defend groups of females in a typical deer strategy of harem following (Alvarez et al., 1975). In some other areas the establishment of leks apparently is associated with high population densities (Clutton-Brock et al., 1988). The absence of any previous observation of leks at Doñana in spite of relatively high eoncentration of animals led us to investigate the mating system of individually recognizable males. Because females concentrate in highly productive patehes of grass at the study area during the rut, a time of low food availability, the spaee perhaps becomes economically defendable for males at this time.

Doñana National Park is located at the estuary of the Guadalquivir River $\left(37^{\circ} 00^{\prime} \mathrm{N}, 6^{\circ} 26^{\prime} \mathrm{W}\right)$. The climate is Mediterranean, with hot dry summers and mild wet winters. Annual rainfall is about $\mathbf{5 3 0} \mathbf{~ m m}$, falling mostly in winter. Mean temperatures range from a January low of $5^{\circ} \mathrm{C}$ to July and August highs of $35^{\circ} \mathrm{C}$.

The dominant features of the park are a seasonal marshland and an area of sands covered by low shrub; the study was concentrated in the ecotone between the two, where fallow deer eommonly oeeur (Braza and Alvarez, 1987). A 260-ha area located in the less disturbed zone, the inner reserve in its southern part, was chosen for our observations. The vegetation consists of low shrubs, brackens, meadows, meadows with rushes, and dry marsh. The area was feneed in a short $(700 \mathrm{~m})$ curvilineal segment on its SE side (Fig. 1 ).

The rut of fallow deer at the study area starts at the beginning of Oetober and lasts about 3 weeks; antler casting oceurs between the end of Mareh and the beginning of May. Young are born at the end of May and beginning of June (Braza et al., 1986). At rutting time after the dry summer, the marsh (of lowest elevation among the habitat types) becomes a vast hard-baked tat covered with dead vegetation. The only relatively moist zones are the meadows and the meadows with rushes, beeause of moisture reserves from a higher water table beneath the more elevated shrub area. As a result, in Oetober, the meadows are well defined with high produetivity (mean aboveground dry biomass in Oetober $1982=299.3 \mathrm{~g} / \mathrm{m}^{2}$ ) as eompared to the shrub area (biomass too small to measure) and the dry marsh $\left(60 \mathrm{~g} / \mathrm{m}^{2}\right)$. Fallow dcer do not eat bracken (Palaeios et al., 1984; Venero, 1984).

At 10-day intervals from 3 August 1986, all individuals of each class (adult and subadult males, females $>1$ year of age, fawns, and yearlings) were counted and their positions plotted on a map of the study area $(1: 2,000)$ divided into 1 -ha squares. Rutting-season observations started on 1 October 1986 and lasted 20 days. By video-reeording males observed in the study area and observing the antlers, most of the 49 males could be recognized individually.

Unlike those in England and central Italy (Apollonio et al., 1989, 1990; Clutton-Brock et al., 1988), fallow deer on our study area are not active at midday during the rut. Their aetivity is largely nocturnal (Braza et al., 1984), a situation apparently common for mammals of the National Park during warm and dry months (Alvarez et al., 1981). Aceordingly, we observed the fallow deer from 0600 to $0900 \mathrm{~h}$ and from 1600 to 1930 $h$ daily during the 20-day rut.

The study area was divided, into four zones, each assigned to an observer, who, positioned in a tower (4$30 \mathrm{~m}$ high), registered the aggressive behavior between males (fighting, chasing, displacing, and parallel walking). The positions of all animals present at $0630 \mathrm{~h}$ and $1700 \mathrm{~h}$ were plotted on a map. Each observation bout lasted 10-15 min and was divided into 1-min intervals. Each male, in turn, was observed. 


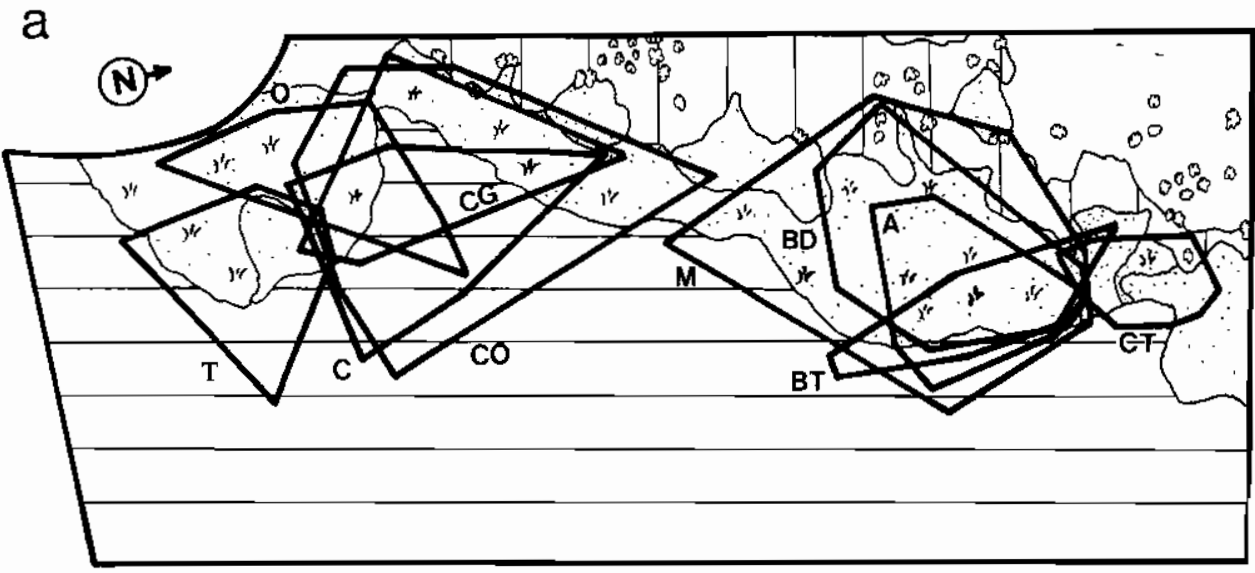

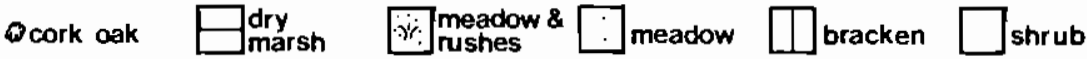

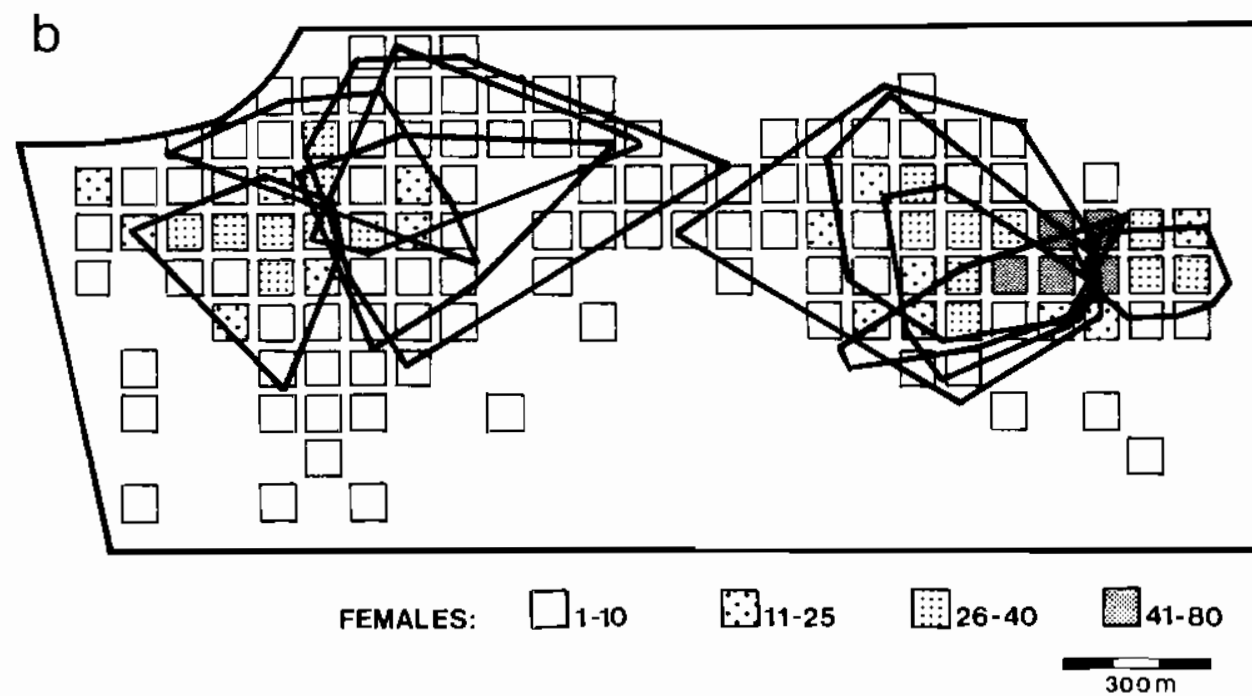

FIG. 1.-Convex polygons of: a, the 10 sedentary fallow deer males during the 1986 rut at Coto Doñana, SW Spain, in the environmental units of the study area based on sighting frequencies; and b, of the 10 sedentary males superimposed upon cumulative number of sightings of females duriug the rut in each 1-ha square. No female was observed in the open spaces. Letters refer to individual males; CT and T were the two territorial males.

An exhaustive search for deer in the study area every 10 days from 2 months before the rutting started provided the number of males and females for each of the 11 sampling days (males, $\overline{\mathrm{X}}=64.4, S D=16.9$; females, $\bar{X}=1248, S D=13.0$ ). Neither the number of animals of each sex uor the sex ratio during the same period ( $\bar{X} \pm S D=1: 2.1 \pm 0.7, n=11)$ showed great variation. The density on the study area was about 73 adults $/ \mathrm{km}^{2}$, which, together with fawns and yearlings, totaled 160 animals $/ \mathrm{km}^{2}$.

Of the 710 sightings of males during Oetober, 266 were of 10 males located in the study area at least 20 times $(\bar{X}=26.6, S D=6.1$; range, $20-39)$. Analysis of behavior was undertaken on these sedentary males, all of them $\geq 5$ years of age. The limits of the rutting areas of these males were defined by conneeting the 
outer locations (eonvex polygons); surfaee areas of the polygons were measured by dividing eaeh into a network of triangles and summing their areas.

In October, both sexes were found most often in the meadows with rushes, meadows, and dry marsh, in deereasing order. The same applied for the 10 sedentary males, for which geometrie centers of locations were mainly in meadows with rushes (six), dry marsh (three), and meadows (one; $\bar{X}=15.4$ ha, $S D=9.5$; range, 4.7-31.5). These 10 rutting areas were arranged in two elusters (Fig. 1a).

Although there is an overlap in rutting areas of individual males, there is much variation in the areas of exclusive use $(\bar{X}=29.6 \%, S D=35.2, n=10$; range, $0-90.8)$; only one individual in eaeh eluster showed almost exclusive use of its rutting area (Fig. 1a).

Most aggressive interactions among males of each cluster involved the territorial male and the next most aggressive individual (39.2\% in the northern cluster and $43.9 \%$ in the southern one) although the two territorial males fought all their neighbors. At no time during the rutting season were either rutting stands (Espmark and Brunner, 1974) or leks observed in the study area. The sedentary males spent most of the most of the time in their rutting areas, following and vigorously herding females feeding therein. Each male retained only temporary control over female groups because females moved freely in and out of a male's zone. The 10 sedentary males occupying the study area, therefore, can be classified as either territorial or harem follower. No other mating strategy was observed.

The location of females in the study area corresponded to a great extent to the rutting areas of the 10 sedentary males (Fig. 1b). Of 1,562 sightings of females during the rutting period, 46\% were within the convex polygons of the two territorial males.

Contrary to the high number of eopulations observed by Clutton-Brock et al. (1988) in England and by Apollonio et al. $(1989,1990)$ in central Italy, where fallow deer appear to be active for the whole daylight period, we observed only seven copulations. This led us to think that they must copulate mostly at night. Of the seven copulations observed, five involved territorial males.

The two territorial males defended their rutting areas even when no females were present; they did not attempt to court females outside their spatial boundaries. This characterizes their behavior as defense of the space itself for reproductive purposes, hence territoriality (Noble, 1939). Because females use the area for obtaining food resources, no leks occur (Bradbury and Gibson, 1983).

Inasmueh as the zones of highest density of females are mostly within the two observed territories, defense of those high resource areas, with the resulting increase of intereeptions of female movemcnts, is probably the first option for any male. As a second choicc, a male may resort to following female groups, defending them against other males. Thus, concentration of females and their predictable movements probably are factors promoting rutting territoriality in male fallow deer, as proposed for various species by Emlen and Oring (1977), Gosling (1986), and Owen-Smith (1977). Red deer (C. elaphus) living in the study area overwhelmiugly resort to resource territoriality as a mating strategy (Carranza et al., 1990), establishing their tcritories also in the productive ecotone between the dry marsh and the shrub.

According to Bradbury et al. (1986), at relatively low densities of females leks would not occur, because the derived reproductive benefits would not exceed the cost of aggregation to males. However, density of females is not the only factor bringing abont leks in fallow deer. Leks are common at San Rossore, where a density as low as 19 animals $/ \mathrm{km}^{2}$ and sex ratio of $1: 1.2$ in favor of females exists (Apollonio et al., 1989, 1990).

If concentration of food resourecs lcads to territoriality, this mating strategy should not be restricted, among the Cervidae, to roc deer (Capreolus capreolus-Bramley, 1970; Kurt, 1968), sika deer (C. nipponMiura, 1984) and red deer (Carranza et al., in press), but should be a commou strategy.

We thank T. Cases for help during field observation, R. C. Soriguer for data on plant production, and M. Festa-Bianchet and J. Carranza for constructive comments. This work was supported by the Comisión Asesora de Investigación Científiea y Técnica of Spain.

\section{Literature Cited}

Alvarez, F., F. Braza, and A Nomzagaray. 1975. Estructura social del gamo (Dama dama, Mammalia, Cervidae) en Doñana. Ardeola, Espeeial, 21:1119-1142.

Alvarez, F., F. Braza, T. Azcárate, E. Aguilera, and R. Martín. 1981 Circadian aetivity rhythms in a vertebrate community of Doñana National Park. Pp. 379-387, in Proceedings of the 15th Conference of Game Biologists (J. Castroviejo, ed.). Estación Biológica Doñana, Sevilla, Spain, 917 pp.
Apollonio, M., M. Festa-Bianchet, and F. Mari 1989. Correlates of copulatory success in a fallow deer lek. Behavioral Ecology and Sociobiology, 25: 89-97.

Afollonio, M., M. Festa-Bianchet, F. Mari, and M. Rrva. 1990. Site-specific asymmetries in male copulatory success in a fallow deer lek. Animal Behaviour, 39:205-212.

Bradbury, J. W., and B. M. Gibson. 1983. Leks and mate choice. Pp. 109-138, in Mate choice (P. 
Bateson, ed.). Cambridge University Press, Cambridge, United Kingdom, $468 \mathrm{pp}$.

Bandbury, J. W., R. Giason, and I. M. Tsai. 1986. Hotspots and the dispersion of leks. Animal Behaviour, 34:1694-1709.

Bramley, P. S. 1970 . Territoriality and reproductive activity of roe deer. Journal of Reprodnetion and Fertility, Supplement, 11:43-70.

Braza, F., and F. Alvarez. 1987. Habitat use by red deer and fallow deer in Doñana National Park. Miscellània Zoològica, 11:363-367.

Braza, F., J. E. Garcín, and F. Alvarez. 1986. Rutting behaviour of fallow deer. Acta Theriologica, 31:467-478.

Braza, F., F. Alvarez, R. Geldof, and H. Byldo. 1984. Desplazamientos de ungulados silvestres a través de una zona de ecotono en Doñana. Doñana, Acta Vertebrata, 11:275-287.

Caranana, J., F. Alvarez, and T. Redondo. 1990. Territoriality as a mating strategy in red deer. Animal Behaviour, 40:79-88.

Chapman, D., and N. Chapman. 1975. Fallow deer. Terence Dalton, Suffolk, England, 271 pp.

Clutron-Brock, T. H., D. Green, M. Hiraiwa-Hasegawa, and S. D. Albon. 1988. Passing the buck: resource defence, lek breeding and mate choiee in fallow deer. Bchavioral Ecology and Soeiobiology, 23:281-296.

EmLEN, S. T., AND L. W. ORING. 1977. Ecology, sexual selection and the evolution of mating systems. Scienee, 197:215-223.

EspmarX, Y., AND W. BRunNer. 1974. Observations on rutting behaviour in fallow deer, Dama dama (Linné, 1758). Säugetierkundliche Mitteilungen, 22:135-142.

GosLing, L. M. 1986. The evolution of mating strategies in male antclopes. Pp. 244-281, in Eeological aspects of social evolution: birds and mammals ( $D$. I. Rubenstein and R. W. Wrangham, eds.). Prince- ton University Press, Princeton, New Jersey, 551 pp.

Heidemann, G. 1973. Zur Biologie des Damwildes (Cerous dame Linné 1758). Verlag Paul Parey, Hamburg, West Germany, 95 pp.

Kunt, F. 1968. Das Sozialverhalten des Rehes ( $\mathrm{Ca}$ preolus capreolus L.). Verlag Paul Parey, Hamburg, West Germany, 102 pp.

MiUnA, S. 1984. Social behavior and territoriality in male sika deer (Cerous nippon Temminek 1838) during the rut. Zeitschreift für Tierpsychologie 64: $33-73$.

Noble, G. K. 1939. The role of dominanee in the life of birds. The Auk, 56:263-273.

OWEN-Smith, N. 1977. On territoriality in ungulates and an evolutionary model. The Quarterly Review of Biology, 52:1-38.

Palacios, F., T. Martínez, and P. Garzón, 1984. Datos sobre la ecología alimenticia del eiervo (Cerous elaphus hispanicus, Hilzheimer, 1909) y el gamo (Dama dama, Linné, 1758) durante otoño e invierno en el Parque Naeional de Doñana. Pp. 445-454, in Actas de la 11 Reunión lberoamericana de Conservación y Zoología de Vertebrados (J. Castroviejo, ed.). Estación Biológica Doñana, Sevilla, Spain, 631 pp.

Pemberton, J. M., AND A. P. BAlmfond. 1987. Lekking in fallow deer. Journal of Zoology (London), 213:762-765.

SchaAl, A. 1986. Mise en évidence d'un comportement de reproduction en arène chez le Daim d'Europe (Dama d. dama). Comptes Rendus de l'Academie des Sciences de Paris, 303:729-732.

SchaAl, A., AND J. W. Bradbury. 1987. Lek breeding in a deer species. Biology of Behaviour, 12:2832.

VENERO, J. L. 1984. Dietas de los grandes fitófagos silvestres del Parque Nacional de Doñana, España. Doñana, Acta Vertebrata, 11:1-136.

Submitted 17 July 1989. Accepted 28 November 1989. 